Diabetologia 8, 358-361 (1972)

(C) by Springer-Verlag 1972

\title{
Isoimmunization of Man by Recrystallized Human Insulin
}

\author{
T. Deckert, O. O. Andersen, E. Grundahl and L. Kerp \\ From Frederiksberg Hospital, Copenhagen, the Steno Memorial Hospital, Gentofte, the State Hospital, Nykøbing \\ Sjælland, Denmark, and the Medizinische Universitätsklinik, Freiburg, GFR.
}

Received: February 28, 1972, accepted: June 20, 1972

Summary. Ten non-diabetic psychiatric patients, who had not previously been treated with insulin, underwent insulin coma therapy by recrystallized, non-monocomponent human insulin in neutral solution. The treatment was given for $1-3$ months, in maximum doses of $96-$ 196 units daily. Several patients formed insulin antibodies. The cause of the antibody formation is discussed. The presence of small quantities of the a-fraction in the insulin is assumed to be of importance in the insulin antibody formation.

Isoimmunisation de l'homme par de l'insuline humaine recristallisée

Résumé. Dix patients non-diabétiques, atteints de maladie psychiatrique, n'ayant pas été traités auparavant par l'insuline, ont subi une thérapeutique par coma insulinique avec de l'insuline humaine contenant plusieurs fractions, recristallisée et mise en solution neutre. Le traitement a été administré pendant $1-3$ mois, à des doses maximales de 96-196 unités par jour. Plusieurs patients ont élaboré des anticorps anti-insuline. La cause de la formation d'anticorps est discutée. La présence de petites quantités de la fraction-a dans l'insuline semble avoir une importance dans la formation des anticorps anti-insuline.

Isoimmunisation des Menschen mit rekristallisiertem menschlichen Insulin

Zusammenfassung. Zehn nicht-diabetische psychiatrische Patienten, die vorher nicht mit Insulin behandelt worden waren, wurden einer Insulinkomatherapie mit einem nicht-monokomponentartigen Humaninsulin in neutraler Lösung unterzogen. Die Behandlung wurde $1-3$ Monate lang mit Maximaldosen von 96-196 E täglich durchgeführt. Mehrere Patienten erzeugten Insulinantikörper. Die Ursache der Antikörperentstehung: wird diskutiert. Die Anwesenheit kleiner Mengen der a-Fraktion des Insulins könnte für die Insulinantikörperbildung von Bedeutung sein.

Key words. Human insulin, insulin antibodies, isoimmunization, impurities in insulin, monocomponent insulin.
The cause of insulin antibody formation in insulintreated diabetics has not been fully elucidated. Various factors must be assumed to play a role. For instance, primary structure of insulin appears to be important, the insulin antibody titre in patients treated with beef insulin being higher than that in patients treated with pork insulin [1]. Furthermore, there seems to be a difference according to whether the insulins are injected in the form of a suspension, of an acid solution with transient precipitation of insulin in the subcutaneous tissue, or in the form of a neutral solution, since insulin antibody formation in man seems avoidable with pork insulin, when the suspension phase is eliminated $[1,8]$. Lastly, it must be considered of the utmost importance that the injected insulins are of a high degree of purity, since associated proteins may potentiate the production of insulin antibody $[6,13]$. A difference in the structure of the injected insulin and the diabetic patient's own insulin does not appear to be of any significance $[3,7]$.

In order to throw further light upon the role of the associated proteins in the production of insulin antibody in man, we studied sera from non-diabetics before and after a 1-3-month treatment with recrystallized human insulin in neutral solution.

\section{Material and Methods}

Ten non-diabetics with psychiatric diseases, not previously treated with insulin, were put on insulin coma therapy. Almost every day they were injected subcutaneously into the thigh, with varying doses of a neutral solution of human recrystallized insulin. The

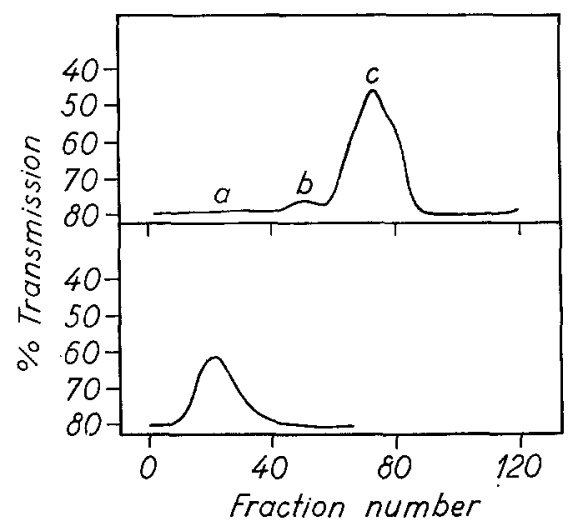

Fig. 1. U.V. transmission of effluent from Sephadex fractionation of human recrystallized insulin (top) and of a-pool (bottom). For details see text. a-pool fraction $10-38$. b-pool fraction $39-56$, c-pool fraction $57-89$ 
duration of the treatment, the total dose of insulin administered to each patient, and the maximum daily dose will be seen from Table 1. The human insulin was prepared in Nordisk Insulin Laboratorium by extraction of pancreases derived from deceased non-diabetics. The process was carried out by special apparatus, excluding any contamination by insulin from other animal species. Microscopic examination of the crystalline suspension showed the crystals to be sharpedged, and in rabbit experiments the hypoglycaemic effect of the preparation was found to be identical with that of pork insulin. Nor was it possible to demonstrate an immunological difference between the human insulin used and recrystallized pork insulin as reported elsewhere [3]. The human insulin was further characterized by dise electrophoresis and fractionation on a Sephadex column.
The polyacrylamide-gel electrophoresis was carried out as described by Davis [5] at $\mathrm{pH} 8.8$ with $0.5 \mathrm{mg}$ of the substance. Following fractionation the gel was stained by Coomassie brilliant blue as described by Chrambach et al. [4].

The fractionation on the Sephadex column was done on a column of $5 \times 84 \mathrm{~cm}$ packed with Sephadex G-50 fine at a flow of $310 \mathrm{ml} / \mathrm{h} .400 \mathrm{mg}$ insulin, dissolved in $5 \mathrm{ml}$ elution fluid, was added. As elution fluid we used $1 \mathrm{M}$ acetic acid $\mathrm{pH}$ 2.25. After recording the optical density of the eluate in an LKB Uvicord, $10 \mathrm{ml}$ fractions were collected. The collected fractions were pooled into 3 pools ( $a, b$, and $c)$ and thereafter freezedried (cf. Fig. 1).

Blood for insulin antibody determination was drawn from the cubital vein on the day before the institution of the insulin coma therapy and 2 days

Table 1. Name, age, duration of insulinistreatment, total insulin dose and the maximum daily insulin dose given of 10 non-diabetic patients with Psychiatric disease never treated with insulin before.

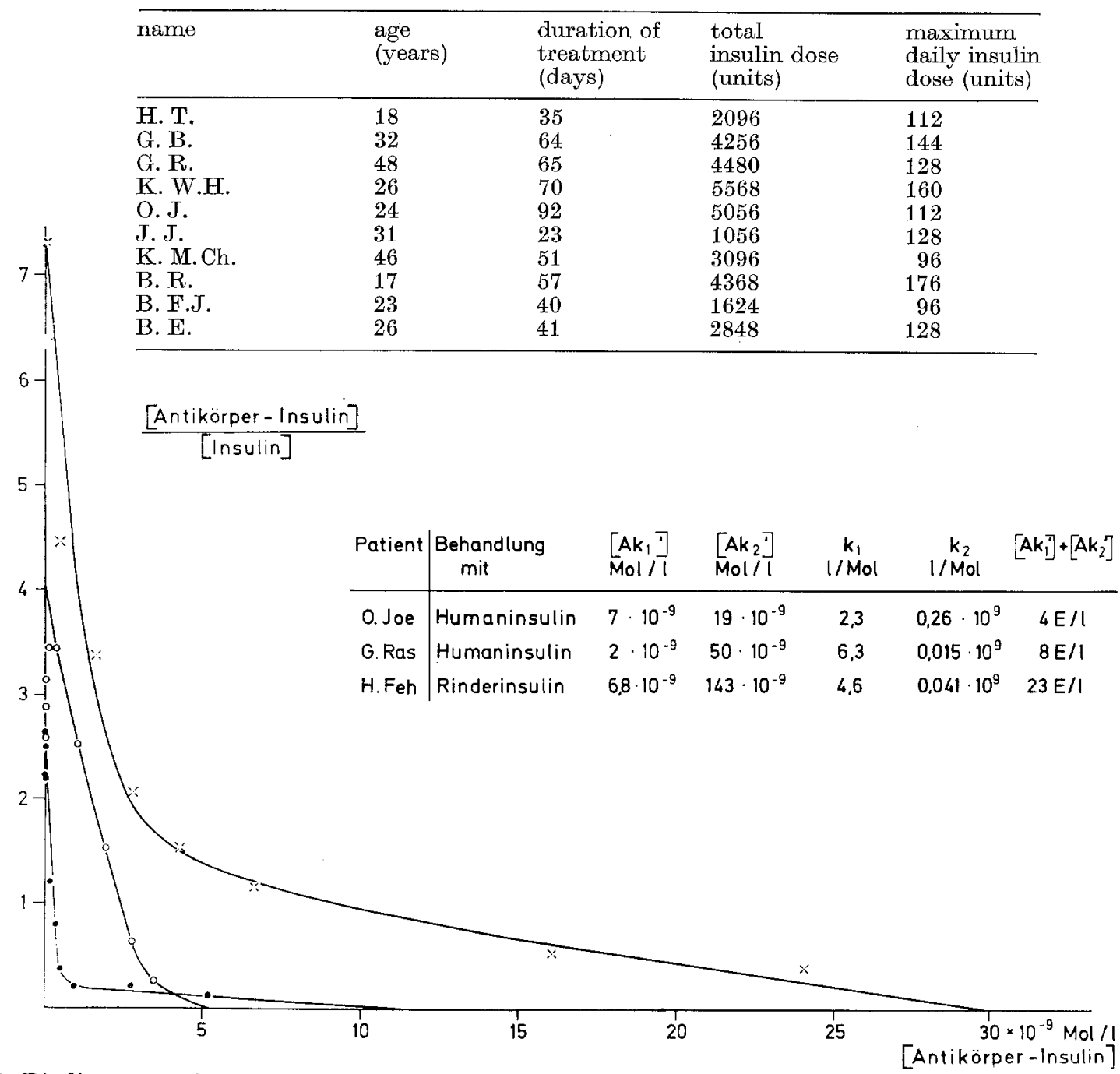

Fig. 2. Binding curve for human insulin to serum from O.J. (o) and G.R. (๑) and binding curve for beef insulin to H.F. (x), a control person treated with beef insulin 
after its discontinuation. The serum was stored at $-20^{\circ} \mathrm{C}$. Blood for serum insulin assay was drawn on the day before the insulin coma therapy was started, both from the fasting patient and 45-60 min after the intake of $50 \mathrm{~g}$ glucose by mouth.

The serum was studied for insulin antibodies:

(a) by the method of Skom and Talmage, modified as stated previously [8],

(b) by the method of Kerp et al. [11], and

(c) by the method of Ortved Andersen [2].

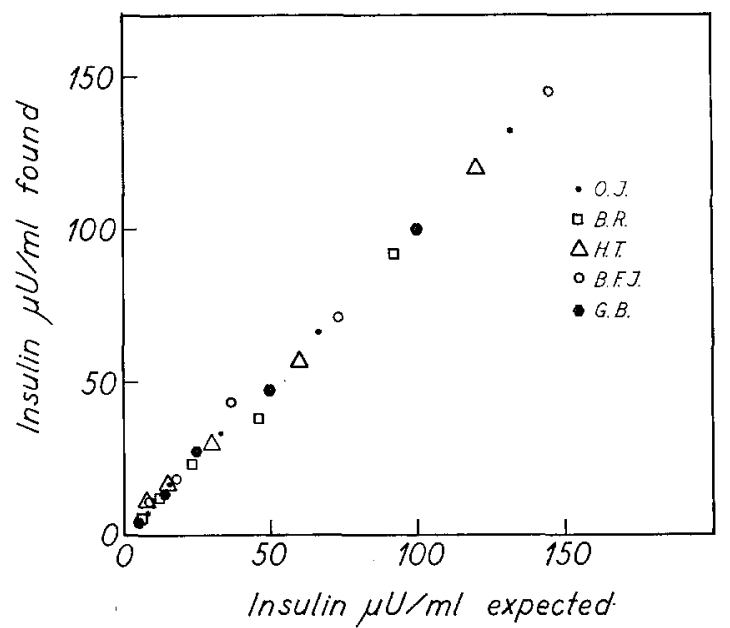

Fig. 3. Serum insulin concentration determined before insulin treatment in undiluted serum and serum diluted $1: 2,1: 4,1: 8$, and $1: 16$ from 5 patients who produced insulin antibodies during treatment with recrystallized human insulin. The linearity of the 5 dilution curves means that no immunological difference could be demonstrated between the circulating insulin in these patients and human recrystallized insulin (7)

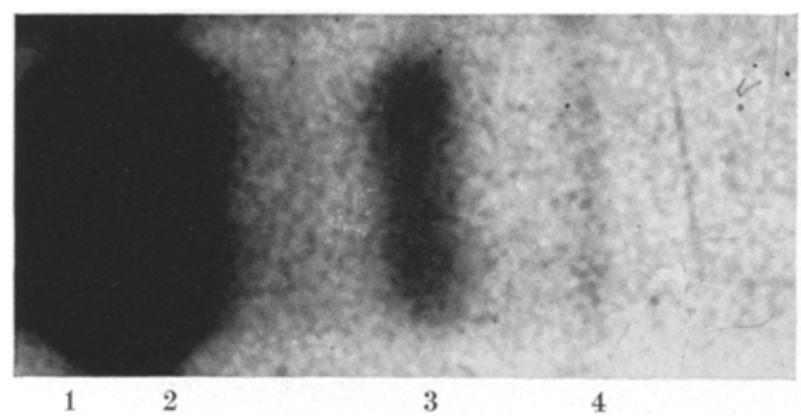

Fig. 4. Photo of human insulin proteins fractionated by polyacrylamide gel electrophoresis. 1 : desamido insulin. 2 : monocomponent insulin. 3 : arginine insulin. 4 : proinsulin

In method (a) the "insulin antibody concentration" was expressed as the percentage of the total quantity of radioactive pork insulin in the system which is bound to the patient's gamma globulins. In noninsulin-treated patients the "insulin antibody concentration" is $0.1-1.2 \%(\mathrm{M} \pm 2 \mathrm{SD})$.

In method (b) the antibodies were characterized from binding curves for human insulin, which form the basis of calculating the total insulin binding capacity. In non-insulin-treated patients the total insulin binding capacity is $<0.014 \mathrm{U} / \mathrm{l}$.

In method (c) the "insulin antibody concentration" was expressed as the quantity of pork insulin in $\mu \mathrm{U}$ which can be bound to $1 \mathrm{ml}$ serum. In non-insulintreated patients the binding capacity is $<32 \mu \mathrm{U} / \mathrm{ml}$.

All the tests were done in duplicate.

The patients' own insulin was characterized by radioimmunological determination of the serum insulin in different dilutions, as reported previously [7]. For radioimmunoassay we used a modification of Heding's method [10]. ${ }^{125} \mathrm{I}$ pork and human insulins were prepared by the method of Greenwood and Hunter [9].

\section{Results}

The results of the insulin antibody study are given in Table 2 and Fig. 2. Whereas no insulin antibodies were demonstrable prior to the treatment, two patients showed insulin antibodies by all three methods after the discontinuation of the treatment. By method (a) it was possible to demonstrate circulating insulin antibodies in another 4 patients. Thus, it is beyond doubt that the treatment with recrystallized human insulin in neutral solution has resulted in insulin antibody formation in some of the patients.

No immunological abnormality of the patients' own insulin could be demonstrated, all serum insulin dilution curves being rectilinear (Fig. 3). The serum from Case G.R. was regrettably spilt.

Polyacrylamide gel electrophoresis of human insulin (Fig. 4) showed the usual bands, i. e. besides the main component and desamido insulin also arginine insulin and traces of proinsulin. Sephadex fractionation also showed the typical appearances (Fig. 1 at the top), i.e. apart from the main component (c-fraction) a small fraction in front of the main fraction (b-fraction), whereas on Uvicord registration it was not possible to demonstrate any a-fraction. After freeze-drying of the pool corresponding to the a-fraction, Sephadex fractionation was carried out on a small column $(1 \times 15.8$ $\mathrm{cm}$ ) at a flow of $4.8 \mathrm{ml} / \mathrm{h}$. Now, it was found that the human insulin contained proteins belonging to the a-fraction (Fig. 1, bottom).

\section{Discussion}

The results obtained by the 3 methods for quantitative insulin antibody determination showed some disagreement, as in 6 patients insulin antibodies were demonstrated by a modified Skom and Talmage technique, whereas by the other two methods antibodies were demonstrated in only two. However, in the 4 cases where the insulin antibodies were demonstrable only by the Skom and Talmage technique the antibody titre was low. As the plasma specimens were thawed 
repeatedly between the various investigations, a resulting reduction of the antibody titre [2] may have contributed to the discrepancy, as the tests by methods $b$ and $c$ were not done until after the completion of the test by method a.

Treatment with non-monocomponent pork insulin in neutral solution rarely gives rise to insulin antibody formation in man $[1,8]$. The antibody formation in such cases may have been caused by the structure of the pork insulin differing from that of human insulin in the amino acid at the C-terminal of the B chain, but the explanation may also be that non-monocomponent pork insulin contains traces of proinsulin and other impurities [13]. The non-monocomponent human insulin used in the present study also contained a protein fraction corresponding, both in disc electro-

\section{References}

1. Andersen, O.: European Association for the Study of Diabetes 6 annual meeting. Warsaw 1970.

2. Andersen, O., Brunfeldt, K., Abildgård, F. : A method for the quantitative determination of insulin antibodies in human plasma. Acta endocr. (Kbh.) 69, $195-208(1972)$.

3. Brunfeldt, K., Deckert, T., Thomsen, J.: Human crystalline insulin from non-diabetic and diabetic. patients Acta endocr. (Kbh.) 60, 543-549 (1969).

4. Chrambach, A., Reisfeld, R.A., Wyckoff, N., Zaccari, J.: A procedure for rapid and sensitive staining of protein fractionated by polyacrylamide gel electrophoresis. Analyt. Biochem. 20, 150-154 (1967).

5. Davis, B.J.: Disc electrophoresis II Method and application to human serum proteins. Ann. N.Y. Acad. Sci. 121, 404-427 (1964).

6. Deckert, T.: Insuliein Antibods. Copenhagen: Thesis, Munksgard 1964.

Table 2. Insulin antibody concentration in patients before and after treatment with human insulin in neutral solution. For methods and normal range, see text

\begin{tabular}{|c|c|c|c|c|c|}
\hline \multirow[t]{2}{*}{ Name } & \multicolumn{2}{|c|}{$\begin{array}{l}\text { Insulin antibody } \\
\text { conc. (a) (per cent) }\end{array}$} & \multirow{2}{*}{$\begin{array}{l}\text { Total binding } \\
\text { capacity (b) } \\
\text { (units } / 1 \text { ) } \\
\text { after treatment }\end{array}$} & \multicolumn{2}{|c|}{$\begin{array}{l}\text { Binding capacity } \\
\text { (c) }(\mu \mathrm{U} / \mathrm{ml})\end{array}$} \\
\hline & before & after & & before & after \\
\hline H. T. & 0.0 & 4.1 & $<0.014$ & 9 & 17 \\
\hline G. B. & 0.2 & 1.9 & $<0.014$ & 5 & 15 \\
\hline G. R & 0.7 & 17.9 & 8.1 & 0 & 41 \\
\hline K. M. W. H. & 0.0 & 0.0 & $<0.14$ & 18 & 32 \\
\hline O. J. & 0.1 & 28.9 & 4.0 & 3 & 96 \\
\hline J.J. & 0.6 & 0.0 & $<0.014$ & 0 & 15 \\
\hline K. M. C. & 0.5 & 0.7 & $<0.014$ & 0 & 4 \\
\hline B. R. & 0.0 & 7.6 & $<0.014$ & 17 & 17 \\
\hline B. F.J. & 0.0 & 3.1 & $<0.014$ & 30 & 8 \\
\hline B. E. & 0.5 & 0.6 & $<0.014$ & 14 & 17 \\
\hline
\end{tabular}

phoresis and in Sephadex fractionation, to proinsulin. Since, however, human proinsulin seems to be a naturally occurring plasma protein [12], it seems rather unlikely that it is the proinsulin component of the insulin used which should be held responsible for the insulin antibody formation.

Accordingly, it seems reasonable to draw attention to other impurities in the human insulin preparation which probably do not occur as natural plasma proteins, viz. desamido insulin, arginine insulin, the intermediary form, dimeric insulin, and in particular proteins of the a-fraction. It has been demonstrated by Schlichtkrull that the a-fraction from pork insulin is the fraction which in rabbits causes most insulin antibody formation [13]. It cannot be ruled out that this may be caused by adsorption of insulin to the high-molecular a-fraction, the insulin acting as a haptene. It can also not be ruled out that this is the mechanism which causes the antibody production in human subjects treated with recrystallized, non-monocomponent human insulin.

Acknowledgements. Our thanks are due to N. N. Andersen, M. Sc., for performing the gel electrophoresis and Sephadex fractionation.
7. Deckert, T., Jorgensen, K.R.: Immunological reactivity of insulin in human serum. Acta endocr. (Kbh.) 53, 673-680 (1966).

8. Deckert, T., Grundahl, E.: The antigenicity of pig insulin. Diabetologia 6, 15-20 (1970).

9. Greenwood, F.C., Hunter, W.M., Glover, J.S.: The preparation of ${ }^{13}$ I-labelled human growth hormone of high specific radioactivity. Biochem. J. 89, 114-23 (1963).

10. Heding, L.G.: A simplified insulin radioimmunoassay method. Proceedings of the Conference on problems connected with the preparation and use of labelled proteins in tracer studies. Pisa: 1966.

11. Kerp, L., Steinhilber, S., Kasemir, H.: Ein Verfahren zum Nachweis insulinbindender Antikörper durch Differentialadsorption. Klin. Wschr. 44, 560-567 (1966).

12. Rubenstein, A.H., Sooja, Cho., Steiner, D.F.: Evidence for proinsulin in human urine and serum. Lancet 1968 I: $1353-1355$.

13. Schlichtkrull, J., Brange, J., Ege, H., Hallund, O., Heding, L. G., Jørgensen, K., Markussen, J., Stahnke, P., Sundby, F., Vølund, Aa.: Proinsulin and related proteins. Lecture held at the 5th annual meeting of the European Association for the Study of Diabetes, Montpellier, 1969.

Dr. T. Deckert

Frederiksberg Hospital

Copenhagen

Denmark 